\title{
Perspectives on Potential Soybean Yield Losses from Weeds in North America
}

\author{
Nader Soltani, J. Anita Dille, Ian C. Burke, Wesley J. Everman, Mark J. VanGessel, Vince M. Davis, \\ and Peter H. Sikkema*
}

\begin{abstract}
Weeds are one of the most significant, and controllable, threats to crop production in North America. Monetary losses because of reduced soybean yield and decreased quality because of weed interference, as well as costs of controlling weeds, have a significant economic impact on net returns to producers. Previous Weed Science Society of America (WSSA) Weed Loss Committee reports, as chaired by Chandler (1984) and Bridges (1992), provided snapshots of the comparative crop yield losses because of weeds across geographic regions and crops within these regions after the implementation of weed control tactics. This manuscript is a second report from the current WSSA Weed Loss Committee on crop yield losses because of weeds, specifically in soybean. Yield loss estimates were determined from comparative observations of soybean yields between the weedy control and plots with greater than 95\% weed control in studies conducted from 2007 to 2013. Researchers from each US state and Canadian province provided at least three and up to ten individual comparisons for each year, which were then averaged within a year, and then averaged over the seven years. These percent yield loss values were used to determine total soybean yield loss in $\mathrm{tha}^{-1}$ and bu acre $^{-1}$ based on average soybean yields for each state or province as well as current commodity prices for a given year as summarized by USDA-NASS (2014) and Statistics Canada (2015). Averaged across 2007 to 2013, weed interference in soybean caused a 52.1\% yield loss. Based on 2012 census data in the US and Canada soybean was grown on 30,798,512 and 1,679,203 hectares with production of 80 million and 5 million tonnes, respectively. Using an average soybean price across 2007 to 2013 of US $\$ 389.81 \mathrm{t}^{-1}\left(\$ 10.61 \mathrm{bu}^{-1}\right)$, farm gate value would be reduced by US $\$ 16.2$ billion in the US and $\$ 1.0$ billion in Canada annually if no weed management tactics were employed.
\end{abstract}

Nomenclature: Soybean, Glycine max (L.) Merr

Key words: Best management practices (BMP), crop losses, economic loss, herbicides, weed management, USA, Canada.

\begin{abstract}
Las malezas son una de las amenazas más significativas y controlables para la producción agrícola en Norteamérica. Las pérdidas monetarias producto de la reducción en el rendimiento de la soja y la disminución en la calidad debido a la interferencia de malezas y al costo de controlar a estas, tiene un impacto económico significativo en la rentabilidad de los productores. Reportes previos del comité de pérdidas por malezas de la Sociedad Americana de la Ciencia de Malezas (WSSA), bajo la dirección de Chandler (1984) y Bridges (1992) brindaron imágenes temporales de las pérdidas de rendimiento comparativas causadas por malezas en diferentes regiones geográficas y cultivos dentro de estas regiones después de la implementación de tácticas de control de malezas. Este manuscrito es un segundo reporte del comité actual de pérdidas por malezas de WSSA sobre pérdidas en rendimiento causadas por malezas, específicamente en soja. Los estimados de pérdida en rendimiento fueron determinados a partir de observaciones comparativas de rendimientos de soja entre testigos con malezas y parcelas con más de 95\% de control en estudios realizados desde 2007 a 2013 . Investigadores de cada estado de Estados Unidos y de cada provincia de Canada brindaron al menos tres y hasta 10 comparaciones individuales para cada año, las cuales fueron promediadas dentro de cada año, y luego promediadas para los siete ańos. Estos valores de porcentaje de rendimiento fueron usados para determinar la pérdida total en soja en $\mathrm{t} \mathrm{ha}^{-1} \mathrm{y} \mathrm{bu}^{\mathrm{acre}}{ }^{-1}$ con base en el promedio de rendimiento de soja para cada estado o provincia y el precio de grano para cada año como lo resumen USDA-NASS (2014) y Statistics Canada (2015). Promediando los ańos de 2007 a 2013, la interferencia de malezas en soja causó un $52,1 \%$ de pérdidas de rendimiento. Con base en los datos del censo de 2012 en Estados Unidos
\end{abstract}

\footnotetext{
DOI: $10.1017 /$ wet.2016.2

*First and seventh authors: Adjunct Professor and Professor, Department of Plant Agriculture, University of Guelph Ridgetown Campus, Ridgetown, Ontario, Canada; Second author: Professor, Department of Agronomy, Kansas State University, Manhattan, KS; Third author: Associate Professor, Department of Crop and Soil Science, Washington State University, Pullman, WA; Fourth author: Assistant Professor, Department of Crop Science, North Carolina State University, Raleigh, NC; Fifth author, Professor, Department of Plant and Soil Science, University of Delaware, Georgetown, DE; Sixth author, Tech Service Representative, BASF, Madison, WI. Corresponding author's E-mail: soltanin@uoguelph.ca
} 
y Canada, se produjo soja en 30,798,512 y 1,679,203 hectáreas para una producción de 80 millones y 5 millones de toneladas, respectivamente. Usando una precio de la soja promedio para 2007 a 2013 de US $\$ 389.81 \mathrm{t}^{-1}\left(\$ 10,61 \mathrm{bu}^{-1}\right)$, el valor en puerta de finca se hubiera reducido en US \$16.6 miles de millones en los Estados Unidos y $\$ 1.0$ mil millones en Canada anualmente si no se hubieran empleado tácticas de manejo de malezas.

Soybean is an important agricultural crop in the United States (US) and Canada, where nearly $8.0 \times 10^{7}$ and $5.1 \times 10^{6}$ tonnes are produced annually on approximately $3.1 \times 10^{7}$ and $1.7 \times 10^{6}$ ha, with an approximate farm gate value of US\$15 billion and US\$1billion, respectively (Statistics Canada 2015; USDA-NASS 2014). The US ranks first in the world in global soybean production, at 31\%, while Canada ranks seventh at $2 \%$ of global soybean production in 2012 and 2013 (FAO 2012; Statistics Canada 2015; USDA-NASS 2014).

Globally, in soybean production, weeds cause the greatest yield loss. Oerke (2006) estimates that, on a global basis, $37 \%$ of attainable soybean production is endangered by weed competition, compared to $11 \%$, $11 \%$, and $1 \%$ by pathogens, animal pests, and viruses, respectively. Weeds compete with soybean for light, water, and nutrients, and can drastically reduce soybean quality and yield. The presence of weeds at harvest time can stain soybean seed and reduce seed quality and harvest efficiency (Burnside 1973; Burnside et al. 1969; Werner et al. 2014).

Weed management research seeks to develop and evaluate diverse weed management strategies and transfer this knowledge to producers to help them employ the best weed management programs that are economically and environmentally sustainable. However, quantitative data on the effects of weeds or other pests on crop yield and quality are very limited. This is because collection of experimental data is time consuming and expensive; the impact of weeds varies between growing seasons because of variation in weed species composition, weed density, and weather patterns; and the impact of weeds can vary considerably across different regions within the US and Canada (Harker 2001; Harker and O'Donovan 2013; Oerke 2006; Walker 1983, 1987). In addition, results can be confounded by other abiotic and biotic factors, including soil properties and soybean cultivars, production practices such as row spacing and seeding rates, and climate change (higher summer temperatures, more extreme weather events).

Despite these challenges, assessment of crop losses is needed to provide support for future action and improved decision-making by producers and governmental agencies (Oerke 2006; Smith et al. 1984). Crop yield loss estimates based on expert opinion have been the norm in the past (Bridges 1992), but these can be influenced by the most recent season and often do not capture the range of yield losses, even among growers in a small geographic area.

Crop improvement through plant breeding has increased soybean yield substantially over the past 30 years (Oerke 2006; Rincker et al. 2014). Production systems have changed significantly, especially for crops like corn (Zea mays L.), soybean, and cotton (Gossypium hirsutum L.). In these crops, the adoption of transgenic hybrids and cultivars has resulted in growers modifying their strategies for pest control in some major production regions including the US and Canada. Agronomists continue to develop and promote optimal crop management practices, including diverse crop rotations, reduced tillage, precision seeding, optimal fertilization rates and timing, and management of other pests such as insects and diseases (Oerke 2006). New herbicides and herbicide-resistant cultivars have been released, including glyphosate-resistant (Roundup Ready®) and glufosinate-resistant (LibertyLink®) soybean. The adoption of glyphosate- and glufosinate-resistant soybean has resulted in a shift in practices towards POST herbicide application and no-tillage crop production, and has changed the composition of weed communities (Vencill et al. 2012). Soybean has become more competitive with weeds, in part because of increased seedling vigor, more rapid early growth, narrower row spacing, and increased seeding rates. However, poor weed control in soybean because of the increased occurrence of glyphosateresistant weed species may increase the potential yield losses observed in some fields. Previous reports on the effect of weeds on soybean yields across North America were based on expert opinion based on observable yield increases after weed control was implemented (Bridges 1992; Chandler et al. 1984; Swanton et al. 1993). Thus, gains in soybean competitiveness may have been masked by increased weed abundance. There is a lack of recent data on the effect of weeds on soybean yield using current 
production practices in various states/provinces in the US and Canada.

There are a limited number of non-survey estimates of yield losses in soybean because of weeds that have been published in the $20^{\text {th }}$ and early $21^{\text {st }}$ centuries. In 1927, the US Department of Agriculture generated the first estimates of global yield losses because of weeds in various crops. (Ultimately, multiple publications were produced by the US Department of Agriculture, as summarized by Cramer [1967].) The Weed Science Society of America's (WSSA's) Weed Loss Committee generated a report in 1984 (Chandler et al. 1984), and updated it in 1992 (Bridges 1992) and 1993 (Swanton et al. 1993), summarizing the crop losses because of weed competition across various geographic regions within the US and Canada. These reports estimated that yield loss in soybean because of weeds can be as high as $27 \%$ in the US and $10 \%$ in Canada. In recent years, Oerke et al. (1994) and Oerke (2006) summarized estimates of losses because of pests on a global basis and reported that potential losses because of weeds in soybean can be as much as 37\%, and actual losses as much as $16 \%$, of the estimated 245 million tonnes of total global production.

The previous reports generated by the WSSA Weed Loss Committee have provided useful information on potential soybean yield losses because of weed interference across various geographic regions of the US and Canada. The Weed Loss Committee is updating previous surveys on the estimated crop losses because of weeds that were published in 1984 (Chandler et al. 1984), 1992 (Bridges 1992), and 1993 (Swanton et al. 1993). More than 23 years have passed since the last report was published, and it will be interesting to determine if there has been any progress in minimizing soybean yield losses because of weeds, considering the fact that there have been significant changes in soybean production systems in the US and Canada. Few reports on crop losses to weeds have focused on the comparative observations of soybean yields between non-treated, "weedy" control plots, and plots with greater than 95\% weed control. Determining soybean yield loss because of weed interference, and the associated economic losses, will provide a knowledge base that can be used to direct research on weed management in soybean in North America (Swanton et al. 1993).

The goal of this WSSA Weed Loss Committee study is to summarize the current extent of soybean yield loss because of weeds, to examine if weeds still cause significant losses, and to determine if there is a need for more research effort in applied weed science. This study is unique in that it estimates soybean yield loss because of weed interference in the absence of any weed management tactics, from replicated, small plot research studies across North America. In contrast, previous Weed Loss Committee reports estimated yield losses based on expert opinion. We collected comparative observations of soybean yield between non-treated plots and treated plots with greater than 95\% weed control from research studies conducted from 2007 to 2013 in the primary soybean-producing regions of the US and Canada. We then used this data to report on the economic impact of weed management in soybean in the US and Canada.

\section{Materials and Methods}

Requests for data were sent to research and/or extension weed specialists in various states and provinces in 2013 and 2014. Each specialist was asked to provide results from up to 10 individual studies on weed control in soybean conducted within a year during the period of 2007 to 2013. Data were also obtained from weed control research reports published online for several states and provinces.

Information requested included: Weedy yield, the average soybean yield from non-treated weedy control plots (using local agronomic practices to promote optimal soybean yield but no weed management tactics), and Weed-free yield, the average yield from plots with $>95 \%$ control for each weed species (using both local agronomic practices to promote optimal soybean yield and excellent weed control). Studies were based on plots without weeds or living cover crops at the time of planting.

Potential yield loss (\%) was determined for each individual study, then averaged within a year, and averaged across the seven years for each state or province:

$$
\begin{aligned}
& \text { Potential Yield Loss }=[(\text { weed-free yield } \\
&- \text { weedy yield }) / \text { weed-free yield }] \times 100
\end{aligned}
$$

State- and province-level data for total soybean ha and acres harvested, average soybean yield in tonnes $\mathrm{ha}^{-1}$ and bushels acre ${ }^{-1}$, total production in tonnes and bushels, and yearly average commodity prices (US\$/bushel) were obtained from the US 
Department of Agriculture National Agricultural Statistics Service (2014) and Agriculture and Agri-Food Canada (2015) reports.

The potential economic loss was weighted by the amount of soybean production within each state or province. The potential monetary loss that each state or province would experience if weeds were not controlled was calculated as the product of the estimated quantity of potential soybean yield loss times the average soybean price. The average soybean price for the period of 2007 to 2013 , US $\$ 389.81$ per tonne (US\$10.61 per bushel), was used to determine the value of the potential loss because of weed interference (AAFC 2015; USDA-NASS 2014).

\section{Results and Discussion}

Data collected in this study represent states and provinces from all the soybean-growing regions in North America and encompass more than $90 \%$ of the soybean grown in the US and Canada (Figure 1). Data were categorized geographically, as they were in the previous surveys of crop losses because of weeds in North America (Bridges 1992; Chandler et al. 1984; Swanton et al. 1993). Table 1 summarizes the data over the 7-year period from 21 US states and the Canadian province of Ontario.

Potential yield loss because of weed interference was $52.1 \%$ when no weed management tactics were implemented, when averaged across the US and Canada. Potential yield losses because of weeds did not follow a consistent trend across the geographic regions reporting. For example, it could be hypothesized that geographic regions with lower soybean yield potential could have greater yield losses because of weed interference, but this was not observed. Average potential yield losses because of weed interference using local agronomic practices to promote optimal soybean yield but no weed control were $32 \%, 55 \%, 61 \%, 51 \%, 51 \%$, and $41 \%$ in the northeastern, Appalachian, Lake, Corn Belt, Northern Plains, and Delta states, respectively.

Based on these calculations, the annual potential soybean yield loss because of weeds across North America is approximately $4.4 \times 10^{7}$ tonnes, which is valued at US\$17.2 billion (Table 2). In the US, potential soybean yield losses were approximately $0.25,2.31,7.42,21.67,7.13$, and $2.16 \times 10^{6}$ tonnes, valued at nearly US $\$ 98$, US $\$ 900$, US $\$ 2,894$, US $\$ 8,447$, US $\$ 2,780$, and US $\$ 840$ million in the northeastern, Appalachian, Lake, Corn Belt, Northern Plains, and Delta states, respectively (Table 1). Among various states, potential soybean yield losses ranged from $29 \%$ for Delaware to $82 \%$ for Kentucky. The potential losses in soybean value ranged from US\$19 million to US\$2,700 million dollars for Delaware and Illinois, respectively (Table 1).

In Canada, the majority of soybean is produced in Ontario. In this province, potential soybean yield
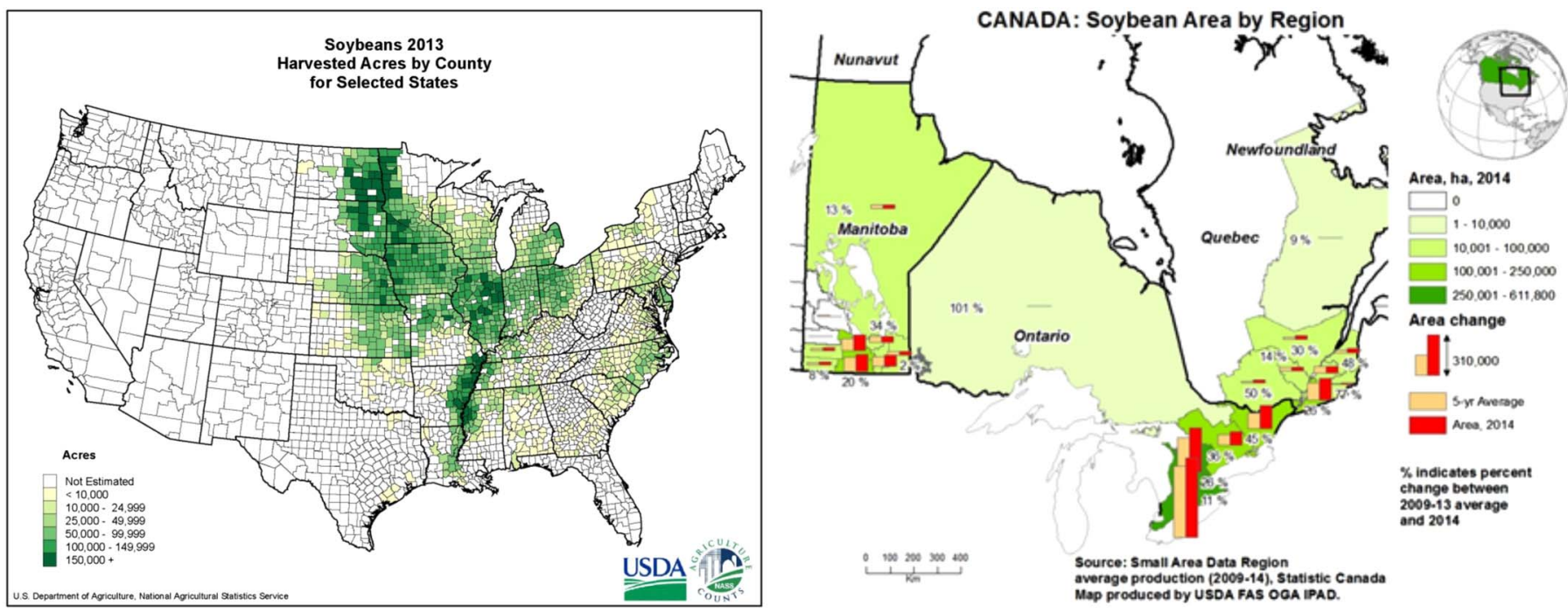

Figure 1. Distribution of soybean hectares (acres) harvested for grain in the United States (2013) and Canada (2011). Images and data from USDA-NASS (2014) and Statistics Canada (2015), respectively. 
Table 1. Average annual potential losses in soybean production and value (US\$) because of weeds for each state or province that provided data for the period of 2007 to 2013. Harvested area (ha and acres) and yield (tonnes or bushels) obtained from the US Department of Agriculture National Agricultural Statistics Service (2014) and Agriculture and Agri-Food Canada (2015). Potential loss in value was calculated using soybean values of US $\$ 389.81$ per tonne or US $\$ 10.61$ per bushel.

\begin{tabular}{|c|c|c|c|c|c|}
\hline $\begin{array}{l}\text { Region } \\
\text { State or province }\end{array}$ & Harvested & Average yield & $\begin{array}{l}\text { Potential } \\
\text { yield loss }\end{array}$ & Potential loss in production & Potential loss in value \\
\hline & $\begin{array}{c}\mathrm{ha} \times 10^{3} \\
\left(\text { acres } \times 10^{3}\right)\end{array}$ & $\begin{array}{c}\mathrm{t} \mathrm{ha}^{-1} \\
\left(\mathrm{bu} \mathrm{acre}{ }^{-1}\right)\end{array}$ & $\%$ & $\begin{array}{c}\mathrm{t} \times 10^{3} \\
\left(\mathrm{bu} \times 10^{3}\right)\end{array}$ & $\left(\mathrm{US} \$ \times 10^{3}\right)$ \\
\hline \multicolumn{6}{|l|}{ Northeast } \\
\hline Delaware & $70(172)$ & $2.40(35.7)$ & 28.7 & $48(1762)$ & 18,698 \\
\hline Pennsylvania & $195(481)$ & $2.97(44.3)$ & 35.2 & $204(7501)$ & 79,581 \\
\hline \multicolumn{6}{|l|}{ Appalachian } \\
\hline Kentucky & $572(1,414)$ & $2.62(39.0)$ & 82.1 & $1,232(45,275)$ & 480,366 \\
\hline North Carolina & $621(1,534)$ & $2.09(31.2)$ & 47.4 & $618(22,686)$ & 240,699 \\
\hline Tennessee & $546(1,350)$ & $2.36(35.1)$ & 36.0 & $464(17,059)$ & 180,992 \\
\hline \multicolumn{6}{|l|}{ Lake States } \\
\hline Michigan & $784(1,937)$ & $2.81(41.8)$ & 62.6 & $1,380(50,685)$ & 537,769 \\
\hline Minnesota & $2795(6,907)$ & $2.78(41.4)$ & 65.3 & $5,083(186,725)$ & $1,981,155$ \\
\hline Wisconsin & $641(1,583)$ & $2.82(42.0)$ & 53.7 & $972(35,703)$ & 378,809 \\
\hline \multicolumn{6}{|l|}{ Eastern Canada } \\
\hline Ontario & $979(2,418)$ & $2.92(43.5)$ & 38.1 & $1,091(40,075)$ & 425,193 \\
\hline \multicolumn{6}{|l|}{ Corn Belt } \\
\hline Illinois & $3,649(9,017)$ & 3.15 (46.9) & 60.5 & $6,964(255,853)$ & $2,714,599$ \\
\hline Indiana & $2,115(5,227)$ & $3.30(47.1)$ & 54.8 & $3,672(134,913)$ & $1,431,427$ \\
\hline Iowa & $3,778(9,336)$ & $3.28(48.9)$ & 46.8 & $5,816(213,656)$ & $2,266,893$ \\
\hline Missouri & $2,091(5,166)$ & $2.52(37.6)$ & 51.5 & $2,723(100,034)$ & $1,061,365$ \\
\hline Ohio & $1,819(4,494)$ & $3.09(46.1)$ & 42.3 & $2,385(87,634)$ & 929,800 \\
\hline \multicolumn{6}{|l|}{ Northern Plains } \\
\hline North Dakota & $1,623(4,011)$ & $2.12(31.6)$ & 61.7 & $2,111(77,570)$ & 823,013 \\
\hline South Dakota & $1,677(4,143)$ & $2.53(37.7)$ & 51.9 & $2,207(81,063)$ & 860,080 \\
\hline Nebraska & $1,046(2,585)$ & $2.89(43.0)$ & 36.3 & $1,098(40,349)$ & 428,106 \\
\hline & $1,438(3,554)$ & 2.26 (33.6) & 52.6 & $1,710(62,812)$ & 666,435 \\
\hline \multicolumn{6}{|l|}{ Delta States } \\
\hline Arkansas & $1,281(3,166)$ & $2.61(38.9)$ & 34.1 & $1,143(41,997)$ & 445,585 \\
\hline Mississippi & $760(1,879)$ & $2.75(41.0)$ & 48.6 & $1,019(37,441)$ & 397,249 \\
\hline
\end{tabular}

Abbreviations: bu, bushel; t, metric tonnes.

losses if local agronomic practices to promote optimal soybean yield were used but weeds were left uncontrolled were $38.1 \%$, which equates to a potential soybean production loss of approximately $1.1 \times 10^{6}$ tonnes, valued nearly at US\$425 million (Table 1 ).

Results from the WSSA Weed Loss Committee study provide quantitative data on the potential soybean yield losses that would occur if producers in North America did not employ weed management tactics but used local agronomic practices to promote optimal soybean yield. The reported losses are much greater than those calculated in earlier reports. This may be because data collected in this study were based on actual plots on research farms or field sites for weed management research, which can sometimes have higher weed populations than commercial fields.
In previous reports, yield loss estimates were based on expert opinion rather than actual field-level data. An earlier WSSA Weed Loss Committee report by Chandler et al. (1984) estimated $13 \%$ to $27 \%$ soybean yield loss across the US, and 9\% across Canada, if weeds were left uncontrolled. Bridges (1992) also reported an estimated $2 \%$ to $20 \%$ soybean yield loss because of weed interference across the $U S$ when using local agronomic practices to promote optimal soybean yield, which increased to $10 \%$ to $60 \%$ soybean yield loss with no herbicidal weed control. In eastern Canada, Swanton et al. (1993) reported 10\% potential soybean yield loss, valued at $\$ 32$ million, when weeds were not controlled. On a global basis, Oerke (2006) estimated the potential yield loss because of weeds in soybean to be $26 \%$ to $29 \%$. 
Table 2. Total annual potential losses in soybean production and value (US\$) because of weeds in the United States (based on 2012 census data from USDA-NASS [2014]) and Canada (based on 2011 Census data from Statistics Canada [2015]). Potential loss in value was calculated using soybean values of US\$389.81 per tonne or US\$10.61 per bushel. The potential loss in production was calculated using a potential soybean yield loss of $52.1 \%$.

\begin{tabular}{lccccc}
\hline Country & Area in soybean & Total production & Value & Potential loss in production & Potential loss in value \\
\hline & ha $(\mathrm{acre})$ & $\mathrm{t} \times 10^{3}$ & $\mathrm{US} \$ \times 10^{3}$ & $\mathrm{t} \times 10^{3}$ & $\mathrm{US} \$ \times 10^{3}$ \\
& & $\left(\mathrm{bu} \times 10^{3}\right)$ & & $\left(\mathrm{bu} \times 10^{3}\right)$ & \\
United States & $30,798,512(76,104,780)$ & $79,663(2,926,823)$ & $31,053,592$ & $41,504(1,524,875)$ & $\$ 16,178,839$ \\
Canada & $1,679,203(4,149,400)$ & $5,087(186,892)$ & $1,982,924$ & $2,650(97,371)$ & $\$ 1,033,124$ \\
Total & $32,477,715(80,254,180)$ & $84,750(3,113,715)$ & $\$ 33,036,516$ & $44,154(1,622,246)$ & $\$ 17,211,963$ \\
\hline
\end{tabular}

Abbreviations: bu, bushel; t, metric tonnes.

This report from the Weed Loss Committee of the WSSA is unique in that the soybean yield loss estimates are based on quantitative data from weed management studies, conducted across the primary soybean-producing regions of the US and Canada. In each of the studies, all weeds were removed prior to seeding soybean with a burndown herbicide application in no-till studies and tillage in conventional tillage studies. Therefore, the soybean yield loss is because of interference from weeds that emerged at, or soon after, the time of soybean emergence. This study concludes that, in the absence of any weed management tactics, soybean yield would be reduced because of weed interference by approximately $52 \%$, a reduction in value of US $\$ 16$ billion annually, in the US, and by approximately $38 \%$, or US $\$ 0.4$ billion annually, in Canada. Soybean is grown on more than $8.0 \times 10^{7}$ acres in North America, with a value of more than US\$33 billion. Slightly more than half of soybean production and economic value across North America could potentially be lost if weeds were left uncontrolled. These data emphasize the continuing need for weed science research to develop integrated weed management strategies that are efficacious, environmentally sustainable, and economically feasible for various soybean producing regions of the US and Canada.

\section{Acknowledgments}

The authors would like to thank the members of the WSSA Weed Loss Committee for their valuable input into this report. We also would like to thank the extension and weed science specialists from Arkansas, Delaware, Illinois, Indiana, Iowa, Kansas, Kentucky, Michigan, Minnesota, Mississippi,
Missouri, Nebraska, North Carolina, North Dakota, Ohio, Pennsylvania, South Dakota, Tennessee, Wisconsin, and Ontario for providing data on the yield losses for their states/provinces.

\section{Literature Cited}

[AAFC] Agriculture and Agri-Food Canada. (2015) Weekly Price Summary. http://www.agr.gc.ca/eng/industry-markets-and-trade/ statistics-and-market-information/by-product-sector/crops/cropsmarket-information-canadian-industry/weekly-price-summary/ $? \mathrm{id}=1378745200250$. Accessed May 20, 2016

Bridges DC (1992) Crop losses due to weeds in Canada and the United States. Champaign, IL: Weed Science Society America $403 \mathrm{p}$

Burnside OC (1973) Influence of weeds on soybean harvesting losses with a combine. Weed Sci 21:520-523

Burnside OC, Wicks GA, Warnes DD, Somerhalder BR, Weeks SA (1969) Effect of weeds on harvesting efficiency in corn, sorghum, and soybeans. Weed Sci 17:438-441

Chandler JM, Hamill AS, Thomas AG (1984) Crop losses due to weeds in Canada and the United States. Champaign, IL: Weed Science Society of America [Special Publication]

Cramer HH (1967) Plant Protection and World Crop Production. Leverkusen: : Farbenfabriken Bayer AG (PflanzenschutzNachrichten Bayer; vol. 20). 524 p

[FAO] Food and Agriculture Organization of the United Nations. (2012) Maize production, FAOSTAT Online Statistical Service. http://faostat.fao.org/. Accessed May 20, 2016

Harker KN (2001) Survey of yield losses due to weeds in central Alberta. Can J Plant Sci 81:339-342

Harker KN, O’Donovan JT (2013) Recent weed control, weed management, and integrated weed management. Weed Technol 27:1-11

Oerke EC (2006) Crop losses to pests. J Agri Sci 144:31-43

Oerke EC, Dehne HW, Schonbeck F, Weber A (1994) Crop Production and Crop Protection: Estimated Losses in Major Food and Cash Crops. Amsterdam: Elsevier Science B.V, 808 p

Rincker K, Nelson R, Specht J, Sleper D, Cary T, Cianzio SR, Casteel S, Conley S, Chen P, Davis V, et al. (2014) Genetic improvements of U.S. soybean in maturity groups II, III, and IV. Crop Sci 54:1419-1432 
Smith IM, Chiarappa L, Van Der Graaff NA (1984) World crop losses: an overview. Pages 213-345 in Wood RKS, Jellis GJ, eds. Plant Diseases: Infection, Damage and Loss. Oxford: Blackwell Scientific Publications

Statistics Canada. (2015) Corn: Canada's third most valuable crop. http://www.statcan.gc.ca/pub/96-325-x/2014001/article/ 11913-eng.htm. Accessed March 25, 2016

Swanton CJ, Harker KN, Anderson RL (1993) Crop losses due to weeds in Canada. Weed Technol 7:537-542

[USDA-NASS] US Department of Agriculture National Agricultural Statistics Service. (2014) Total herbicide applied, and the proportion of US corn acres treated with herbicides, 1990 to 2014. http://www.nass.usda.gov/Surveys/Guide_to_ NASS_Surveys/Chemical_Use/2014_Corn_Highlights/index.asp. Accessed May 20, 2016

Vencill WK, Nichols RL, Webster TM, Soteres JK, MallorySmith C, Burgos NR, Johnson WG, McClelland MR (2012) Herbicide resistance: toward an understanding of resistance development and the impact of herbicide-resistant crops. Weed Sci (Special Issue): 2-30

Walker PT (1983) Crop losses: the need to quantify the effects of pests, diseases and weeds on agricultural production. Agric Ecosyst Environ 9:119-158

Walker PT (1987) Losses in yield due to pests in tropical crops and their value in policy decision-making. Insect Sci Appl 8: 665-671

Werner EL, Curran WS, Lingenfelter DD (2014) Management of eastern black nightshade in agronomic crops: an integrated approach. Pennsylvania: Penn State Extension. (Agronomy Facts 58). $6 \mathrm{p}$

Received July 2, 2016, and approved October 10, 2016.

Associate Editor for this paper: Aaron Hager, University of Illinois. 